\title{
Cost comparison of three kinds of compression therapy in venous ulcer ${ }^{*}$
}

\author{
Bruno Emmanuel de Medeiros Pereira ${ }^{1}$ \\ Jael Rúbia Figueiredo de Sá França²
}

\author{
Alana Tamar Oliveira de Sousa ${ }^{2,3}$ \\ Maria Júlia Guimarães Oliveira Soares ${ }^{2}$
}

DOI: http:/ / dx.doi.org/10.1590/abd1806-4841.20162980

\begin{abstract}
Evolution and cost of three types of compression therapy (single layer, multilayer and Unna boot) in patients with venous ulceration were compared. The evaluation lasted two months and used photographic records and instrument based on pressure ulcer scale for healing (PUSH). Treatment with monolayer compression therapy presented the lowest cost and more efficacy of the three types, with $82 \%$ savings compared with the multilayer therapy.
\end{abstract}

Keywords: Case studies; Compression bandages; Nursing; Varicose ulcer

The venous ulcer (VU) is a worldwide problem which causes considerable socioeconomic impact, burdens health services and compromises life quality of patients and their families. It represents $70 \%$ to $80 \%$ of leg ulcers. ${ }^{1,2}$

Compression therapy is an efficient form of treatment for $\mathrm{VU}$, because it can combine bed care with the treatment of venous hypertension. ${ }^{2,3}$ Due to the need of understanding how the treatment of this type of lesion should be done - especially compression therapy - and the choice of a product according to its cost, benefit and adequacy to the patient's profile, this study had the objective of comparing the evolution and cost of VU treatment using three types of compression therapy.

Three different types of therapy were used with VU patients undergoing outpatient clinic treatment. The patients were treated for practically the same length of time. The first patient was treated with inelastic compression therapy with Unna boot for 63 days; the second one was treated with multilayer compression therapy for 62 days; the third one was treated with single-layer compression therapy for 62 days as well.

For data collection, an evaluation instrument based on pressure ulcer scale for healing (Push) and photographies were used.

Unna boot therapy was applied in a 53-year-old patient, male, hypertensive, who presented VU above the medial malleolus in the left lower limb (LLL) for the last four years. In the first evaluation, before the first round of Unna boot therapy, the lesion had an extension of $68 \mathrm{~cm}^{2}$ and showed granulation tissue and copious exudate. The primary dressing contained silver foam and barrier cream on the edges. In the last evaluation, the ulcer measured $65.1 \mathrm{~cm}^{2}$ and exhibited granulated tissue and moderate exudate. The same type of primary dressing was maintained. For 11 applications, the cost of Unna boot with the dressing was $\mathrm{R} \$ 1.317,75$. These was closure of $4.2 \%$ of the lesion during the 63 days of treatment.

Multilayer compressive therapy was applied on a 47-yearold patient, male, hypertensive, with VU for three years, located in

Universidade Federal de Campina Grande (UFCG) - Campina Grande (PB), Brazil. 
the lateral medial third of LLL. Before the first application of the multilayer bandage system, the lesion measured $210.8 \mathrm{~cm}^{2}$ and contained slough and little exudate. In the primary dressing, nylon tissue with silver was used, associated to polyurethane foam. In the last evaluation, the wound measured $76.5 \mathrm{~cm}^{2}$, granulation tissue and moderate exudate. The primary dressing was changed to polyurethane foam with silver and barrier cream at the edges. The cost of 13 curatives with dressings and the multilayer system was R\$ $5.331,11$. The closure of $63.7 \%$ of the lesion could be observed during the 62 days of treatment.

Singlelayer compression therapy was used in a 62-year-old patient, female, hypertensive, with VU for 12 years in the frontal part of LLL, between the malleoli. Before the first application of singlelayer long-stretching elastic bandage, the lesion measured $21.1 \mathrm{~cm}^{2}$, with granulated tissue and moderate exudate (Figure 1). The primary dressing was done with calcium alginate and barrier cream at the borders. In the last evaluation, an ulcer spanned an area of $0.6 \mathrm{~cm}^{2}$, with epithelialized tissue and scarce exudate (Figure 2). Primary dressing was changed to polyurethane foam with silver and barrier cream at the borders. At the end of 62 days of treatment, the cost of 21 curatives was $\mathrm{R} \$ 958,62$ and closure of the wound reached $97.1 \%$.

The treatment with singlelayer long-stretching elastic bandage was the cheapest and the most efficient of the three types. A study found that the use of singlelayer therapy can save from $51 \%$

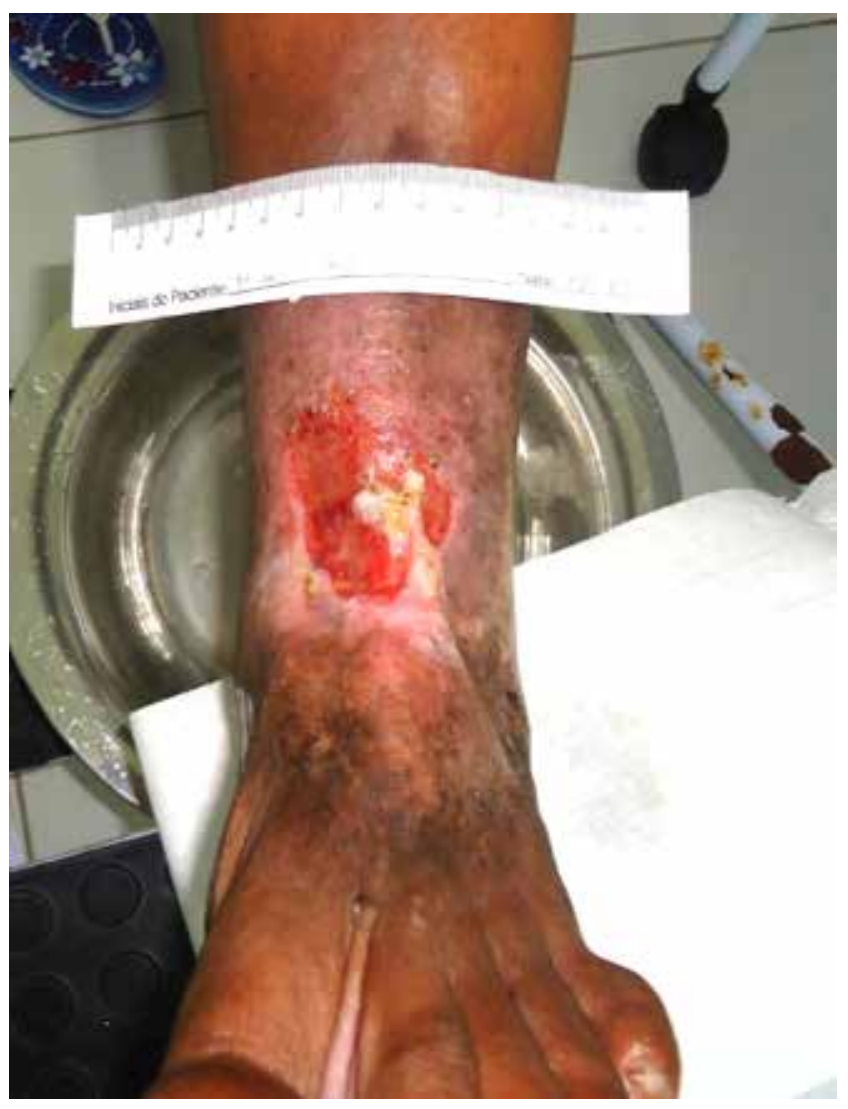

FiguRE 1: First evaluation, before the use of single-layer elastic bandaging system
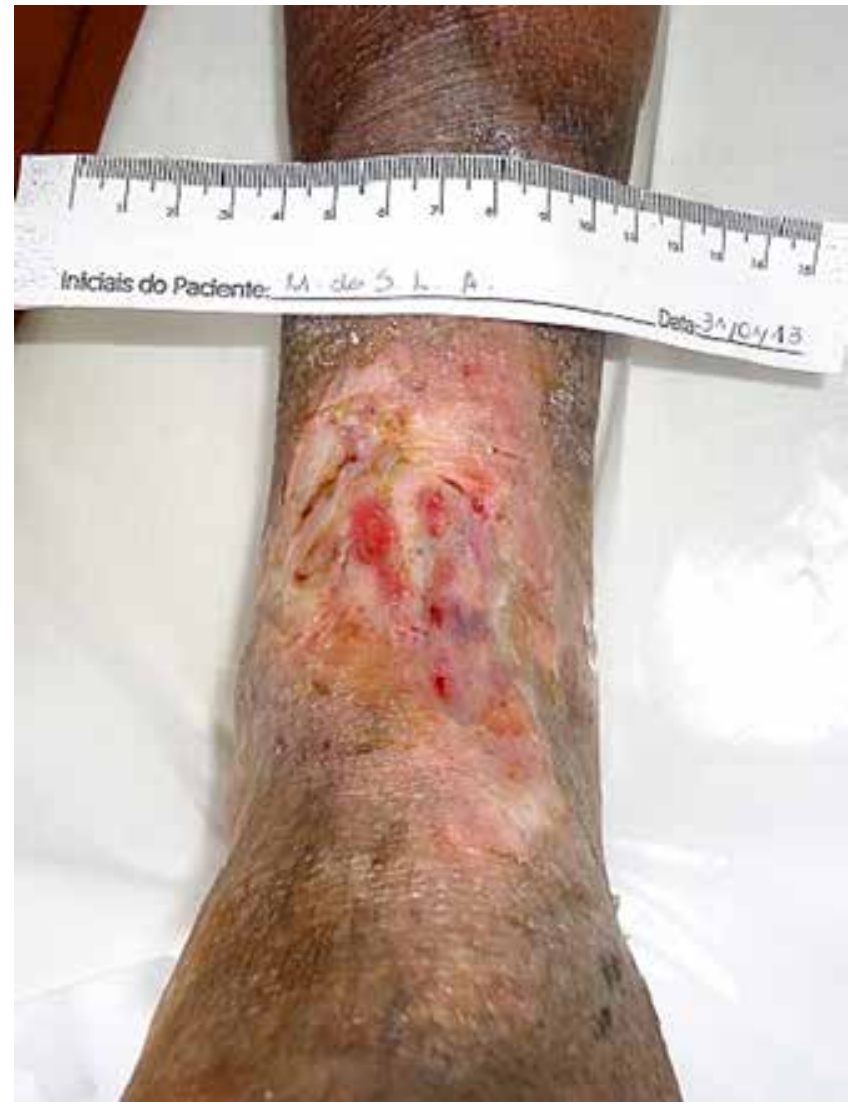

Figure 2: Last evaluation of the single-layer bandaging system, after 62 days of use

to $63 \%$ in costs in comparison with multilayer therapy. ${ }^{4}$ In this study, there were savings of $82 \%$ compared to multilayer therapy.

Regarding cicatrization, the ulcer with the largest diameter in this study $\left(210 \mathrm{~cm}^{2}\right)$ on which the multilayer system was applied, presented $22.2 \%$ of closure in only 62 days, which shows that the cure of this lesion was faster than in a randomized study in which a $\mathrm{VU}$ of the same diameter was healed in 280 days through the same system. ${ }^{5}$

For the patient who used the multilayer bandaging system, there was significant reduction of pain and improvement in mobility, which allowed him not to use crutches, upon which he depended to walk around, right after the start of the therapy.

A review done by Cochrane Data Base concluded that the multicomponent systems are more effective than singlecomponent ones, however the multicomponent systems that contain elastic binding seem to be more effective than those with nonelastic components. ${ }^{6}$ This way, the elastic therapy seems to be more effective for treating VU than Unna boot, apart from the number of layers, which is confirmed in this study.

This study revealed that therapy with single-layer bandage was the cheapest and with the shortest time of cicatrization, being also a good option when the available financial resources are scarce.] 


\section{REFERENCES}

1. González-Consuegra RV, Verdú J Quality of life in people with venous leg ulcers: an integrative review. J Adv Nurs. 2011;67:926-44.

2. Conferencia Nacional de Consenso sobre Úlceras de la Extremidad Inferior (Conuei). Documento de consenso. Barcelona: EdikaMed; 2009.

3. Abbade LPF, Lastória S. Management of patients with venous leg ulcer. An Bras Dermatol. 2006;81:509-21.

4. Pham B, Harrison MB, Chen MH, Carley ME; Canadian Bandaging Trial Group. Cost-effectiveness of compression technologies for evidence-informed leg ulcer care: results from the Canadian Bandaging Trial. BMC Health Serv Res. 2012;12:346.

5. Milic DJ, Zivic SS, Bogdanovic DC, Perisic ZD, Milosevic ZD, Jankovic RJ, et al. A randomized trial of the Tubulcus multilayer bandaging system in the treatment of extensive venous ulcers. J Vasc Surg. 2007;46:750-5.

6. O'Meara S, Cullum N, Nelson EA, Dumville JC. Compression for venous leg ulcers. Cochrane Database Syst Rev. 2012;11:CD000265.
MAILING ADDRESS:

Alana Tamar Oliveira de Sousa

Universidade Federal de Campina Grande (UFCG)

Centro de Educação e Saúde (CES)

Unidade Acadêmica de Enfermagem (Uaenfe)

Sítio Olho d'Água da Bica, S/N, sala 17

58175-000 - Cuité - PB

Brasil

E-mail:alanatamar@gmail.com

How to cite this article: Pereira BEM, Sousa ATO, França JRFS, Soares MJGO. Cost comparison of three kinds of compression therapy in venous ulcer. An Bras Dermatol. 2016:91(4):544-6. 